\title{
DIY Urbanism as a Tool of Urban Regeneration. Two Cases in Comparison
}

\author{
Paolo Robazza $^{1}$, Danila Longo ${ }^{2 *}$, Giulia Bortoli $^{3}$, Giulia Alese $^{4}$, Andrea Boeri $^{2}$ \\ ${ }^{1}$ Department of Architecture, University of Strathclyde, Glasgow, G1 1XQ, United Kingdom \\ ${ }^{2}$ Department of Architecture, University of Bologna, Bologna 40126, Italy \\ ${ }^{3}$ Independent Researcher, Bologna 40126, Italy \\ ${ }^{4}$ Independent Researcher, Rome 00176, Italy
}

Corresponding Author Email: danila.longo@unibo.it

https://doi.org/10.18280/ijsdp.150301

Received: 20 May 2019

Accepted: 3 January 2020

\section{Keywords:}

urban regeneration, collective construction site, social activation, codesign, self-construction, co-construction, temporary architecture, public space

\begin{abstract}
A process of urban regeneration should be able to produce social and spatial contextual effects. In order to achieve long-term results, it has to guarantee social inclusion. New rising ways of transformation of public space, consisting in the urban co-design, are defining new tools able to trigger processes of regeneration so called "community-led". One of the approaches used by different groups of architects to trigger regeneration processes of so-called "in need areas" is the activation of the community through urban laboratories of social innovation for the realization of temporary transformations of space. This article explores the analysis of DIY (Do It Yourself) Urbanism tools of co-planning and co-construction as motors of innovation, activation and social inclusion, investigating their role in urban regeneration. Questions are being asked about the new skills of the architect involved in these procedures and about possible tools useful to the institutions to act in these operative fields. The purpose is to analyze some practices, hypothesizing their replicability and applicability to different scales, in order to generate virtuous mechanisms. Two experiences of co-design and coconstruction, located in two different geographic, social and political contexts, will be shown: the construction of the Casa de la lluvia (de ideas), in Bogotà (Colombia), and the regeneration of Piazza Gasparotto, in Padua (Italy). Despite the peculiarities of context, we want to illustrate the strategies implemented in the cases exposed, in order to identify shared features and differences due to the degrees of freedom that the participation tools must have, to be flexible and repeatable.
\end{abstract}

\section{INTRODUCTION}

In spite of different approaches and interpretations about this topic, the urban regeneration is defined as the integrated set of strategies and actions aimed at the long-term development of the cities; this virtuous process of economic, physical, environmental and social transformation [1] can take action effectively within "susceptible to change spaces", in the urban pattern, that is in those "in need areas", as Ostanel [2] reports. This is a particular kind of neglected and obsolescent public property/use spaces [3] which fail to express their potential of catalysts of collective dynamics, because of their condition of marginalisation and social stratification in addition to the lack of ontological, symbolic, functional and, sometimes, legislative recognition. The origin of these criticalities in Western cities is ascribable to the failure of the traditional urban planning that has ignored the social implications of the territorial transformations [4] carrying-out utilitarian and based on the quantity ideas. This situation was aggravated by the most recent Welfare State crisis as a result of which the public spaces' management has been conducted as non-priority issue in Public Administrations' agendas. On the other side, the large South American cities in developing Countries are affected by a late urban planning characterized, since the 70's, by the application of the North American neoliberal approach. This condition has increased the socioeconomic inequalities and favored dynamics of informal appropriation of the territory, producing, on one side, spatial fragmentation [5] and favoring the consolidation of the local associative fabric, on the other; in fact the inhabitants are cohesive in precariousness and active in the processes of social and political recognition [6].

In order to explain more exhaustively this topic, two cases studies deemed significant are outlined below: the interventions for the redevelopment of Piazza Gasparotto in Padua, Italy, led by BAG studio - Beyond Architecture Group, and the construction of the Casa de la lluvia (de ideas) in Bogotà, Colombia, coordinated by the collective Arquitectura Expandida. The selection of these two examples, located in very different political, social and environmental situations, is useful to the study: it's considered that the specific contextual features add variable factors to the methodology, testing its flexibility and showing similarities and differences.

\section{METHODOLOGICAL APPROACH}

In so called "in need areas" it's possible to identify degrees of operational freedom such as to hypothesize experimental process scenarios for urban regeneration, through projects of 
temporary architecture and participatory processes in both phases of co-design and co-building. These are methods belonging to the framework of "DIY (Do It Yourself) urbanism" and "tactical urbanism" [7] but not yet studied as tools of urban regeneration. This study aims to investigate the validity of a methodology that connects the design and formal aspects with those of the process, asking what are the social and collective dynamics that can be triggered by it. So, dealing marginally with architectural field, the point of view is focused on these new strategies of "collective engagement" [8] meant as possible tools for reconstitution of proximity relationships in the communities and reaffirmation of the "right to the city" understood as the right to work, to the participating activity, and the right to fruition [9].

The cases are addressed through a critical reflection on the processes of temporariness, co-planning and self-construction and on how they can take on the value of urban regeneration tools. The reflection also affects the role of the architect involved in these processes and the dynamics of replicability of the applicable strategies.

\section{URBAN REGENERATION AND NEW TOOLS OF COLLECTIVE PARTICIPATION}

Cities are facing rapid changes in response to deindustrialization, international migration, economic globalization and climate change [10]. As La Varra [11] reports, it is no longer a question of the recovery or urban renewal of the 70's, nor of urban redevelopment in the 80's and 90's. In the face of these practices implemented in the past and aimed at specific areas (historic centers, abandoned industrial areas, etc.), the regeneration referred to can potentially involve whole city, including "a broader range of actions" through a holistic approach and acting on the interrelations that bind the microcosms which the city is composed of [12]. The degradation of entire urban areas and the fragmentation of the landscapes that make up city are not only a reflection of the economic impoverishment and of public administrations' instrumental and cultural inadequacy in managing the anthropic space, but they are also the consequence of increasingly unstable and conflicting social geographies, of phenomena of ethnic specialization and marginalization, of the separation between individual, community and territory [2]. In order to reconstruct these fractures and thus to trigger lasting processes of urban regeneration, it's strategic to operate on the so-called "social activation levers" [13], that is, on those dynamics capable of bringing innovation and social inclusion through collective actions. The "activation levers" of the co-planning and coconstruction processes can be generated in the communities of citizens who, once equipped with the appropriate tools, can become urban development agents and promoters of innovation also towards the institutions. Therefore, "the capacity to aspire" and the "institutional learning" are key factors in the participatory processes thus understood.

"The capacity to aspire" [14] is defined as "cultural capacity", that is the awareness of knowing how to do and being able to act proactively on change. This is increased by the empowerment of collective capabilities [15], through tools of social innovation aimed at transforming citizens from carriers of needs into carriers of action, starting up so-called "community-led" regeneration processes. Among these strategies, the urban labs of social innovation are of particular relevance: these are laboratories coordinated by organizations of architects who uses the tools of co-design and co-building to regenerate "in need areas". "The capacity to aspire" takes place, in these contexts, through the "learning by doing": the "community of practice" [16] that is set up during the phases of participation is called to analyze the needs and problems, to identify the objectives and to make choices; it also deals with finding sources of funding and, not least, building the designed architectural device. At the time of shared planning, therefore, follows the time of construction as a moment of active participation: this phase is called "collective construction site". It's an innovative urban laboratory which, involving citizens in "temporary communities of practices" [16] aimed at the design and construction of architectural works, uses professionalism and appropriate technologies, in order to implement relational dynamics and social activation.

The two moments of participation, and particularly that of the "collective construction site", are new contexts of action in which individuals, initially destabilized by novelty, must relocate, with mutual respect and with the shared goal to completing a project [16]. This operation is essential for selfrecognition in the production process and in the reconstitution of a collective vision. After the phases of co-creation, the community becomes more cohesive and provides the experimentation, testing the correspondence of the results with the expected forecasts and possibly starting a new planning process [17]. The social innovation generated by community's participation in co-planning and self-construction of temporary architectures couldn't be a factor of urban regeneration if it weren't accompanied by an institutional recognition [18]. An initial difficulty arises from the need to recognize the legitimacy of these methodologies. If the institutions pose themselves in a hostile manner towards such experiments, even the result of the processes is endangered (this is the case of the actions in informal settlements in Bogotà). Alternatively, under the pressure of these bottom-up social activation initiatives, a virtuous path of mutual learning between institutions and communities of technicians and citizens can be launched: it is defined as "institutional learning". The objective is developing new institutional tools capable of operatively accompanying these procedures to make them enter into a reproducible and enlargeable praxis, in the logic of facilitating social inclusion. Some actions in this direction have been done, for exemple, in Bologna, through the "Collaboration Pacts" as defined by art. 5 of the "Regulation on collaboration between citizens and Administration for care and the regeneration of urban commons" approved by the Municipality of Bologna in 2014 in collaboration with the Social Promotion Association, Labsus - laboratory for subsidiarity, and the Monte di Bologna and Ravenna Foundation [19]. These Collaboration Pacts establish from time to time how to support citizens who selforganize interventions on public space and promote new initiatives to involve citizens in operations aimed at urban regeneration. Among the known experiments there are the Urban Living Labs, the laboratories that accompany the regeneration projects by testing new cooperation strategies and public-private partnerships $[20,21]$ with the ambition to produce long-lasting effects. 


\section{THE ROLE OF TECHNOLOGY AND OF THE ARCHITECT IN THE REGENERATION PROCESSES}

The need to use low executive difficulty solutions for temporary architectures in "collective construction site" implies a careful technological research in the design phase. Temporariness on one hand is connected to the use of appropriate technology for works made in self-construction by not-expert people, on the other it is a strategic experimental element $[9,22]$. In fact, constructing lightweight devices with low environmental and economic impact materials, it's possible to test the structure through post-occupancy evaluation. So the possibility of being took down, if it doesn't comply with the intended uses, is implicitly considered and validated, constituting a further project data, where it is intended to hypothesize dismantling aimed at reusing the parts. Added to this - in cases where there isn't an institutional recognition of the self-construction processes, as in the informal neighborhoods of the South American metropolises it's to highlight the precariousness linked to the substantially abusive nature of the interventions. In these situations dismantling is considered as calculated risk, internal to the limit between legality and legitimacy in which one operates.

The architect has a key role to play in the processes of participatory planning and self-construction of temporary structures. Managing these practices, the architect has to carryout a particular "modus operandi". Co-design and coconstuction processes offer ample space for experimentation and easier accessibility even for young professionals. On the other side an extension of the field of the architect's skills is required. At first, the architect should know how to engage other professionals, to institute multidisciplinary teams. The more the pattern of specializations involved in the phases of co-planning and co-creation is multiple and variously composed (sociologists, psychologists, artisans, artists, economists ...), the more the process acquires value in the perspective of regeneration; but the role of the architect becomes more complicated [11]. In fact, in addition to communicate efficiently with all other professionals, the architect should discern the phases in which to make theme intervene, putting the various disciplines at the service of the process according to their specifities. Then the architect should be able to mediate and to facilitate the communications between community and institutions, favoring moment of confrontation (architect as mediator). Moreover, the architect should educate the community in research of own needs and capabilities, to facilitate citizens' activation in urban transformation process (architect as educator). Another fundamental task of the new architect is to generate and transfer technological and pragmatic knowledges useful to menage effectively the "collective construction site" of selfconstruction, even solving possible problems occurring during the building (architect as builder). In this case, he invades the disciplinary domain of the craftsman to educate the community about the relationship with matter and "manual" thinking. Finally, the architect involved in this kind of actions concerning urban regeneration shows features of social and political activism (architect as activist), since he is a spokeperson of necessity, developing an approach to architecture based on the needs of the communies and the defense of the environment, as well as on accessibility to public spaces. In light of this complexity, it is considered appropriate to rethink the educational path of the new generations of architects (as Friedman [23] defines "barefoot architects"), meaning the architecture no longer as a unique technique-disciplinary field, but as a complex system of specificity. The design collectives Arquitectura Expandida and BAG have adopted in the two cases presented a method that presents various analogies. Although in the Colombian case the aspect of militancy and political struggle of the architects is more evident, both contexts have engaged the designers not only in their role as technicians but also and above all as process facilitators. Since the multidisciplinary nature of these experiments involves anthropological, technological, architectural, as well as public policy issues, the design teams have tried in both cases to provide skills and tools adequate to this complexity. They have made use of the active commitment of professionals from different disciplinary areas, such as in Bogotà, or have sought these resources among the co-creator citizens, as in Padua. In both cases, the architects spent more the time on facilitation than on planning, using communication and management skills not usually required in traditional vertical design processes. The project is no longer offered univocally by the designer to the client, but it is the result of the horizontal dialogue between citizens, professionals and institutions. In this context, architects are called upon to implement new strategies to best express the technical and creative potential of the various actors. The research is focusing precisely on these aspects, trying to codify procedures and methodologies to facilitate these innovative processes.

\section{PIAZZA GASPAROTTO (ITALY) AND CASA DE LA LLUVIA (DE IDEAS) (COLOMBIA): COMPARING TWO EXPERIENCES OF SELF-CONSTRUCTION}

Two experiences of participatory design and construction are referred to illustrate some dynamics for the regeneration and constitution of new public spaces, through strategies of engagement of the communities. These are the construction sites for the regeneration of Piazza Gasparotto in Padua, Italy, and for the building of Casa de la Lluvia (de ideas) in Bogotà, Colombia; these processes have been led respectively by the study of architecture BAG - Beyond Architecture Group and the team of Arquitectura Expandida.

These two cases have been selected because representative of two similar approaches in different contextual situations. The paduan work is located in a square appearing as an urban void resulting from the failure of the urban planning which has led to degradation this area in the city, whereas the Colombian experience is sited in a "barrio informal", therefore lacking both in legislative recognition and basic facilities, in an environmental context characterized by different orographic and ecological peculiarities. The level of social cohesion that can be found in the two cases differs, too: on one side the organizations in Piazza Gasparotto are heterogeneous and lack a common identity but the one set up a little earlier just for the project of regeneration of the square, on the other, the community active in the building of the Casa de la lluvia (de ideas) is cohesive and politically militant for long time before this self-construction process. Moreover, it's necessary to analyze the role of self-construction in both these contexts. In Italy, self-construction is an archaic practice, even if it's not unknown. Despite its deep roots, it is seen today as an experimental procedure because it isn't coherent with common practice. So the "collective construction site", like the one of Piazza Gasparotto, involves a "temporary communities of 
practices" in a pragmatic construction of an architectural device in order to achieve a shared goal: this approach reproduces collaborative dynamics similar to the pre-industral rural ones, in which mutual aid and worksharing was useful to solidify the social pact [24]. Through self-construction, therefore, an operation to recreate relationships of proximity in the communities is carried out, resulting in a reappropriation of the sense of belonging of the public space. Instead in the Colombian context self-construction is an endemic phenomenon, since it's rooted in the wider culture of settlement informality in marginal neighborhoods. Through this practice the disadvantaged inhabitants, driven by primary needs and supported by a strong internal cooperative spirit, are transformed into the main social agents of urban growth. Therefore, they build precarious informal settlements without planning, basic facilities and public spaces. The absence of the social role of the State and the institutional censure of the survival strategies put in place by people have fed the development of the "informal city". In this way the inhabitants reclaim "their right to the city" [5] fighting continuously [25]. Self-construction in this context aims at the building of "beautiful and designed for citizens" cities, through collective actions [26, 27].

In spite of the various distinctions, it is possible to reconstruct a framework of adhesions in the management of the two processes. In fact both the groups of architects gather professionals who mean the architecture as a social issue: a tool rather than an aim. BAG and Arquitectura Expandida approach to the professional practice in a multidisciplinary and experimental manner. They carry out a research model based on the collective action and on a continuous testing and analysis of procedures and results. Their work doesn't finish with the delivery of the architectural device, but it goes on during use phases of the structures, in order to improve the methodology and to correct future processes. This feedback loop is defined by Lefebvre [9] as "transduction and experimental utopia".

\subsection{Piazza Gasparotto, Padua (Italy)}

Piazza Gasparotto is a square of $2.200 \mathrm{sqm}$, located near the Padua railway station. The marginal position and the funcional void caused by the vacant buindings around, have led this area to deep conditions of neglect, allowing criminal actions and drug dealing. These circumstances worsened an already difficult situation characterized by a demographic pattern composed of seniors over 65 years old, migrants and asylum seekers, and people in needs.

In 2014 the Cooperativa Est rented some spaces in the buildings around the square and activated a coworking called $\mathrm{CO}+$, available for free for those companies who would commit to co-design of the square. This propulsive bottom-up action has undergone a further acceleration in 2015 with GasparOrto project made by a community of landscapers; this project aimed at the creation and care of small urban vegetable gardens in the square. In that circumstance several organizations transversely active on the territory have begun to gravitate around the site. The associations and the social organizations in Piazza Gasparotto (cooperativa EST, HUBFood, Culture and Sport, Nadir, ASD Parkour Wave, Officine Arte Teatro, Associazione Giovani Produttori Agricoli AGIA), with institutional partners as the Municipality of Padua, Banca Popolare Etica and the University of Venice IUAV, won the contest "Culturability 2016", funded and promoted by
Fondazione Unipolis. The winner project, "LAB+: Piazza Gasparotto Urban Living Lab", consisted on a plan of reappropriation of the public area through actions of cultural and social innovation, gardening practices and infrastructural works [28, 29].

The studio of architecture BAG - Beyond Architecture Group was involved in this project to design a new configuration of the space. The architects proposed to the associations active in Piazza Gasparotto a new experimental path of co-design and co-building, through a "collective construction site" [30]. The co-design phase took place in a series of meetings useful for identifying the objectives and planning actions for the realization of temporary devices. These ones would be able to fulfill the needs expressed by the inhabitants and to offer new missing functions, without affecting the integrity of the existing structures, working in addition and using completely reversible solutions.

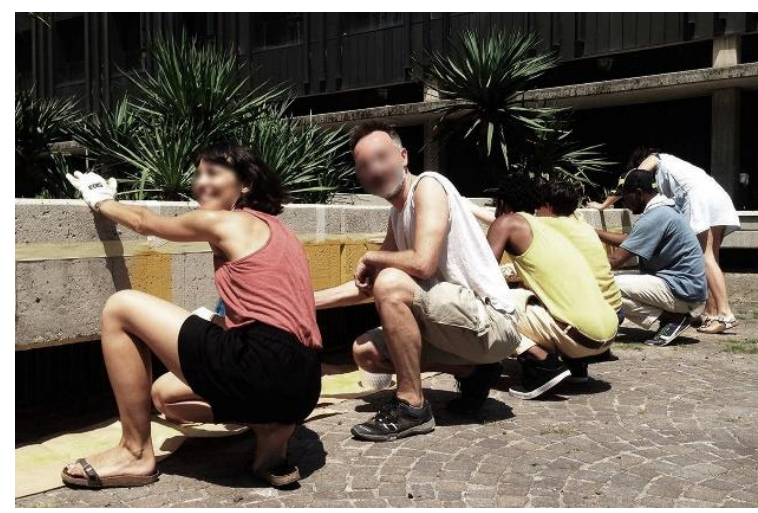

Figure 1. Citizens working in the collective construction site of Piazza Gasparotto

In addition to the search for the new image to be given to the square, a long dialogue was begun with the institutions, in order to see the legitimacy of the process recognized. Citizens, designers and institutions implemented a path of mutual knowledge, learning the implied dynamics in the new participation tools ("institutional learning"). An innovative and sometimes conflicting procedure has been launched, and it has opened a necessary debate within the public administration and between it and the citizens.

Once the design of the space was defined and the necessary authorization process was completed, the "collective construction site" was started. A large and heterogeneous community of migrants, students of architecture and ordinary citizens who were in addition to the associations of the square were involved simultaneously with the specialized building enterprise. The so composed "temporary communities of practices" was busy with "appropriate" operations, quite simple to be done in self-construction, as shown in Figure 1. Collective moments took place, as lunches and coffee breaks, to slow down the rhythm of working and to allow moment of socialization. In order to increase social integration, these phases are as important as the building of the architectural devise. In addition to the execution of the work, the construction site involved the community creatively, calling the co-creators citizens to take detailed design decisions also during the construction phase. This space of freedom had been previously planned by the architects, leaving project areas open to improvisation: the positioning of the benches, their attachment to the ground, the height of the colored edges of the tanks and other micro-details that generated new moments 
of confrontation on site, renewing the collaborative climate. This strategy has increased the sense of satisfaction in the recipients of the operation and has helped to create unexpected architectural configurations: we could talk about creative "random noise", a term borrowed from the field of biology and applied to architecture. It is an interference of improvised elements that "can give the project a vital force that sometimes the classical architectural design cannot offer" [28].

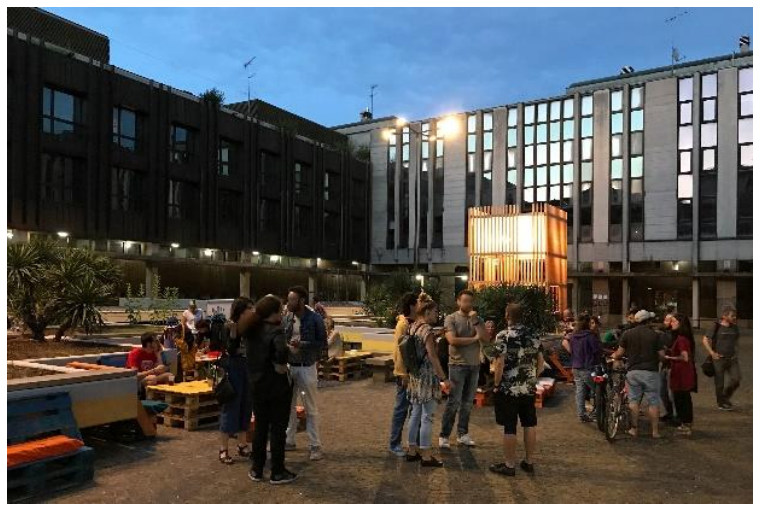

Figure 2. Collective event in Piazza Gasparotto after the first works of regeneration

After a few months from the construction of the first temporary structures and some events in the square, as shown in Figure 2, the associations of the square activated independently a new phase of participatory planning and selfconstruction, demonstrating they had acquired new "capabilities" during the first laboratories. This new phase made it possible to verify the lack of compliance between the intended uses and the real uses of the devices implemented. The "failure" of some solutions has shown that the unknowns related to the dynamics of a public space are in part unpredictable at the design level, and so they must be tested. The "collective construction site" has therefore inaugurated a renewed push towards the care and enhancement of the square, as evidenced by the rapid planning of activities open to all citizens [31]. This experience shows that this increased awareness of the community and the attention to maintenance, in perspective, constitutes an important factor of urban quality. Sharing the results of an innovative process of regeneration of a public space guarantees the social inclusion necessary for the regeneration of the whole city.

\subsection{La casa de la lluvia [de ideas], Bogotá, Colombia}

La Casa de la lluvia [de ideas] is a cultural and communitary space located in La Cecilia pirate urbanization district (UPZ 32, San Blas), on the south-eastern outskirts of the city of Bogotá. The district, not yet legalized at the beginning of construction, is situated in the eastern mountains, on the urbanrural border with the Delirio forest reserve and belongs to the fourth town of San Cristóbal, in turn inserted into the sub-basin of the Fucha river, an area of great environmental value. The town was one of the first settlements that arose outside the city and contributed profoundly to the urban expansion of the twentieth century, largely due to the phenomenon of informal urbanization following the violence of the 1950s and the need for housing of migrants and displaced people. The vast majority of this phenomenon has affected areas of high risk for erosion and landslides in the eastern mountains, currently defined by the POT (Plan de Ordenamiento Territorial) as a "rural and protected area". Here La Cecilia, along with six other districts, constitutes the Alto Fucha zone, an isolated area characterized by a profound deficit of services and public spaces, in which the relationship with the environmental element is of vital importance. To the precariousness and isolation are added the consequences of state interventions due to the legalization processes and the environmental plans of the Secretaría Distrital del Hábitat which provide, among other things, the relocation of half of the population currently established in risk zones and protected areas [32].

The engagement of the collective by the Municipal Action Council (JAC) takes place in 2012. The project stems from the need to have a municipal salon in which to meet and constitute the first case of positive collaboration between Arquitectura Expandida and community leaders. From this need it's elaborated a dry structure in guadua (Colombian bamboo), polycarbonate and zinc plates, of dimensions $10 \mathrm{~m} \times 5.5 \mathrm{~m}$, placed on a lot of the result excluded from the original process of pirate subdivision as unsuitable for building. The building is distributed on two levels: A multi-use ground floor and a mezzanine that will house a library connected to the network of the local Community Libraries. From the outset, the interest and participation of the community, in particular of its more mature range, prove to be very strong and the times of the construction site are distributed during every Sundays for eight months to allow everyone to participate. The fact of having such an extended period of time gave Arquitectura Expandida the opportunity to plan an own and real process of construction and cultural management at the intern of "physical and social self-construction" of the territory [33]. In addition to the inhabitants of La Cecilia, the process sees the interaction of various actors, local and otherwise, divided into a heterogeneous and multidisciplinary group in line with the nature itself of the collective and its vision of "expanding" the boundaries of architecture towards others disciplines, mainly involving the artistic collectives active in the territory. The idea is to provide a common operational base in order to create a network that connects existing realities in a strongly disconnected context. La Casa de la lluvia [de ideas] is constituted as a project-laboratory in which the participation process is articulated in all the phases of the work, from conception to final management, and is accompanied by a series of functional strategies to the appropriation and social and cultural activation of both the building and the territory, in a perspective of integrated self-management. Fundraising is part of the complex issue of self-management and is distributed among the participants according to the means available to them.

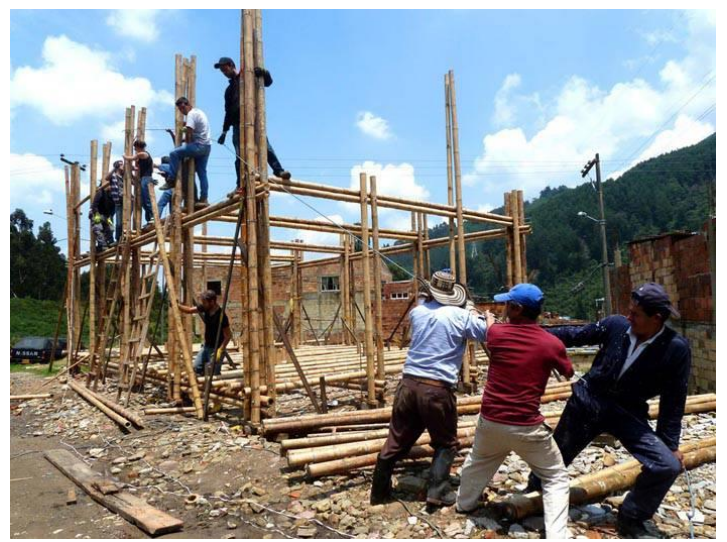

Figure 3. Casa de la lluvia (de ideas): self-construction phase 
Very important were the laboratories aimed at creating a feeling of territorial identity: through them we try to make the space a place of dialogue and inclusion and to bring out the cultural potential of the community. Historical memory workshops and documentary journalism on the history of the district, emotional maps, text-context readings, workshops related to cultural techniques and local construction alternated with moments of community celebration are functional to the "territorial self-diagnosis" phase and to increase the feeling of community and collaboration. Even children are included in the participation in the role of active citizens and are involved in play and self-construction activities so that they can become aware of their abilities and identify themselves as creators of changes in their own space.

The choice of guadua as a material is part of a precise strategy that aims to facilitate the physical self-construction phase, as shown in Figure 3, and support both the "pedagogical" aspect of the construction site and the environmental awareness [27, 33, 34].

The physical, social and cultural construction of La Casa de la lluvia [de ideas] is a progressive process that is distributed over time and follows dynamics linked both to the resources and to the management and use of space by the community, applying, also for public space, the model of progressive housing typical of Latin American private construction [33]. Following this rhythm, the building has been transformed from the static idea of a municipal salon into a dynamic and multiuse community space, a perfectly integrated and activated reference point in the cultural and social life of the Alto Fucha, where the community can exercise its citizenship and devise strategies of creative resistance in response to the processes of expulsion and relocation initiated by the government $[35,36]$. One of the physical testimonies of these manifestations is precisely the large mural shown in Figure 4, created during the "Cecilazo" along the longitudinal wall of La Casa de la lluvia [de ideas], conceived and painted by the community to communicate to the users of the district the desire for territorial belonging and the community struggle that is lived daily in the urban margins [36].

The collective assumes a "political-critical position" towards the figure of an "absent" State, promoter of a rigid penalizing and excluding regulatory apparatus, according to the collective, which harms access to fundamental urban rights to the entire population [27]. Given these premises, it's understood how the whole implementation process has not followed any bureaucratic procedure, raising the controversy between legality and legitimacy, between the politicaladministrative aspect and the right to live and inhabit one's own habitat. The complexity of the relations between communities and institutions proved to be evident also following the approval of the process of legalization of the district in 2015 and the subsequent proposal by the Public Administration to expand the Casa de la lluvia [de ideas] through public funding [37].

The nature of the funds, tied to the loss of the rights to selfmanagement of space, and the lack of agreement between the interlocutors led the community to refuse the investment (2017). In March 2019, taking advantage of the fortunate availability of resources from the community and the collectives, a new phase of self-construction was started which sees again involved Arquitectura Expandida, the Community of La Cecilia and the collectives Arto Arte and Huertopia Fucha. The new intervention that involves replacing the surface coating of the roof and three of the four walls, choosing to preserve the "murals of dreams", added to other small interventions, demonstrates the desire to safeguard and protect its space over time and to reiterate the strength and capacity of the community self-management as a response to the sociospatial segregation of the popular sectors.

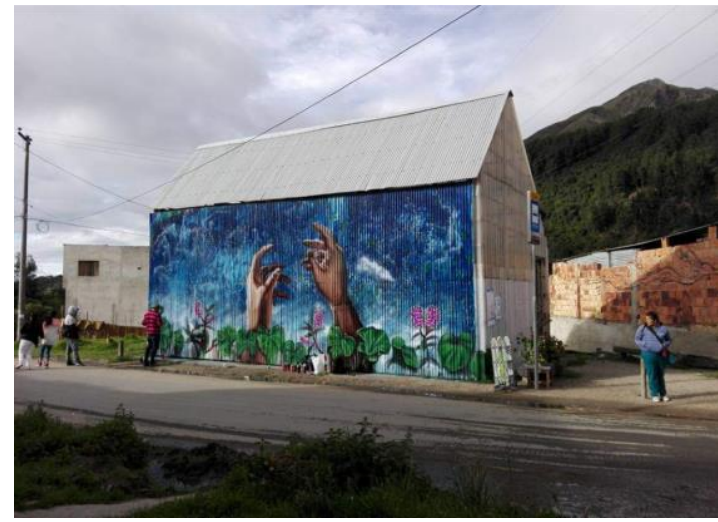

Figure 4. Physical testament of creative resistance: mural painted during the "Cecilazo" along a wall of La Casa de la lluvia (de ideas)

La Casa de la lluvia (de ideas) represents the right of assembly in public space as a democratic meeting place [33] and states how the Arquitectura Expandida projects seek to respond to the need for popular culture to have iconic buildings to identify with, which could be the symbol of a goal and of a collective request within the struggle for the right to be recognized. La Casa de la lluvia [de ideas] is the fruit of the fifth meeting of Arquitectura Expandida and, in chronological order, is subsequent to La Casa Del Viento, a project in which the collective reaches a methodological maturity applied to participatory practice and integral architectural development. The outcome and the evolution of the path show how the collective action aimed at recovering and building public spaces, combined with a conscious proposal promoted from below, can generate a positive response in the social fabric of a territory and be an example of inclusive construction of city [38].

\section{CONCLUSIONS}

This study aims to increase the debate and to identify shared features in co-design and co-creation processes, in order to develop reproducible methodologies.

In the two cases presented, self-construction led to the "capacity to aspire" of communities and institutions, providing useful tools for urban regeneration, through actions on public space. The innovative activation labs prove to be useful in triggering "community-led" processes that endure over time because they are able to activate a dialogue with institutional actors. This dynamic, held in different ways in the two contexts, led to the initiation of a debate within the administrations ("institutional learning") and between these ones and the communities. The acknowledgment of the existence and usefulness of new co-creation processes is the first step in a process of knowledge and construction of new institutional operational tools, able to enhance the contribution of the communities. It is clear that regeneration operations through temporary interventions in self-construction can also be useful for public administrations to test city transformation 
procedures and strategies. This can be possible through monitoring the reactions of citizens and users, verifying results and planning structured and innovative actions that open new reflection fronts through a circular research-action-research approach. The methodologies implemented in the co-planning and co-construction processes have proved to be effective in providing communities of citizens with new capabilities, new tools that facilitate their empowerment. The "capacity to aspire" was functional to generate further processes of social activation aimed at urban regeneration. Moreover, small-scale temporary structures have been functional to a constant verification and therefore to a greater correspondence between objectives and results. This process has led to a greater involvement of the actors and consequently to a greater durability and effectiveness of the regeneration process. Among the main obstacles and difficulties encountered in both projects there were: the scarce availability of financing that forced the designers to identify solutions often at the limit of sustainability; the complexity of the relationship with the law which, not supporting this type of action, does not allow groups of designers to act within a clear framework of reference; the bureaucratic difficulties that can often slow down the process and therefore the monitoring of the results, that would be useful for defining future strategies of action on the city.

The results obtained can therefore inaugurate new strategic actions on the built devices: disposal (with possible re-use of elements and material recycling), in the case of poor compliance with expectations, or maintenance and implementation, in the presence of a positive response. In this last case a step-by-step development of the device can be considered with the enrichment of the methodological framework. This research suggests as open issued the role of the architect in co-design and co-construction processes both in informal and in formal city, and the role of institutions in facilitation of bottom-up actions.

\section{REFERENCES}

[1] Roberts, P., Sykes, H. (1999). Urban Regeneration. A Handbook. Sage Publications Ltd, London. http://dx.doi.org/10.4135/9781446219980

[2] Ostanel, E. (2017). Spazi Fuori Dal Comune. Rigenerare, Includere, Innovare. Franco Angeli, Milano.

[3] The Charter of Public Space. (2013). Biennale dello Spazio Pubblico.

[4] Magnaghi, A. (2000). Il Progetto Locale: Verso La Coscienza di Luogo. Bollati Boringhieri, Torino.

[5] Torres Tovar, C.A. (2009). Ciudad Informal Colombiana: Barrios Construidos por La Gente. Universidad Nacional de Colombia, Facultad de Artes, Bogotá.

[6] Torres Carrillo, A. (2011). Organizaciones populares, construcción de identidad y acción política. RLCSNJ, 4(2).

[7] Lydon, M., Anthony, G. (2015). Tactical Urbanism: Short-Term Action for Long-Term Change. Island Press, Washington, DC. https://doi.org/10.5822/978-1-61091567-0

[8] Romice, O.R., Frey, H.W. (2003). Communities in Action. The handbook. Scottish Arts Council, Glasgow.

[9] Lefebvre, H. (2014). Il diritto alla città. Trans. Gianfranco Morosato. Ombre corte, Verona.

[10] Gianfrate, V., Longo, D. (2017). Urban Micro-design.
Franco Angeli, Milano.

[11] La Varra, G. (2016). Architettura Della Rigenerazione Urbana. Forum Edizioni, Udine.

[12] Buzzone, A. (2015-2018). Il contributo dell'innovazione sociale alla rigenerazione dei paesaggi urbani. $\mathrm{PhD}$ Thesis. Università di Roma "Sapienza".

[13] Lazzarino, E. (22 March 2018). Personal communication. U-rise master. IUAV University, Venice, Italy.

[14] Appadurai, A. (2013). The Future as Cultural Fact. Essays on the Global Condition. Verso, London; New York.

[15] Sen, A. (1985). Commodities and capabilities, NorthHolland; Amsterdam; New York; Oxford.

[16] Marcorè, E. (2018). Building with the quak. Earthquake and Reconstruction in L'Aquila. Thesis in Anthropology. School of Social Sciences, Department of Anthropology, University of Aberdeen.

[17] Sanoff, H. (2000). Community participation methods in design and planning. John Wiley \& Sons, New York.

[18] La Cecla, F. (1995). Mente locale. Per un'antropologia dell'abitare. Editrice Elèuthera, Milano.

[19] Iperbole, rete civica. Il percorso e il regolamento. http://partecipa.comune.bologna.it/il-percorso-ed-ilregolamento, accessed on May, 07, 2019.

[20] Boeri, A., Bortoli, G., Longo, D. (2019). Cultural heritage as a driver for urban regeneration. WIT Transactions on Ecology and the Environment, 217: 587598. https://dx.doi.org/10.2495/SDP180501

[21] Steen, K., Van Bueren, E. (2017). The defining characteristics of urban living labs. Technology Innovation Management Review, 7(7): 21-33. http://doi.org/10.22215/timreview/1088

[22] Udayasuriyan A. (2016). Bottom-up Urbanism in temporary Urban spaces. Master thesis. École Polytechnique de l'Université François - Rabelais de Tours.

[23] Friedman, Y. (2009). L'architettura di Sopravvivenza. Una Filosofia Della Povertà. Bollati Boringhieri, Torino.

[24] Fathy, H. (1973). Architecture for the poor: An experiment in rural Egypt. The university of Chicago press: Chicago, London.

[25] Torres Carrillo, A. (2000) Organizaciones y luchas urbanas en América Latina. Balance y perspectivas. Estudios Latinoamericanos, UNAM, 7(14): 97-131. http://dx.doi.org/10.22201/cela.24484946e.2000.14.523 21

[26] Engaging Community, Engaging Practice. Arquitectura Expandida. Should designers be outlaws? Curry Stone Foundation, Social Design Insights Podcast. https://currystonefoundation.org/practice/arquitecturaexpandida accessed on May, 04, 2018.

[27] Colectivo Arquitectura Expandida. (2015). Espacios de Juego al Límite: Conflicto y autogestión territorial de espacios públicos a través de tres estudios de caso en Bogotá. III Seminario Internacional de Procesos Urbanos Informales, Universidad Nacional de Colombia, Bogotá.

[28] Ostanel, E., Robazza, P. (2017). Contemporaneo. Far rivivere uno spazio pubblico nel quartiere della Stazione di Padova. Zaffagnini, A., (Ed). An3, architetti notizie, Ordine degli A.P.P.C. della Provincia di Padova, 01: 2325.

[29] Culturability, Fondazione Unipolis. Cultura Ricerca Sicurezza Solidarietà. La nostra tappa a Padova con $\mathrm{LAB}+, 07$ dicembre in Notizie - Share. 
https://culturability.org/notizie/la-nostra-tappa-apadova-con-lab/ accessed on Apr. 2, 2019.

[30] Beyond Architecture Group (BAG). Appropriate Technologies for a Sustainable Architecture. Piazza Gasparotto Urban Living Lab. Padova, Italia, 2017. http://www.bagstudio.org/piazza-gasparotto-urbanliving-lab/ accessed on Apr. 4, 2019.

[31] Piazzagasparotto, http://piazzagasparotto.org/accessed on Apr. 4, 2019.

[32] Alcaldía Mayor De Bogotá D.C., Programa de las Naciones Unidas para los asentamientos humanos - UN HABITAT, Universidad Nacional De Colombia Instituto De Estudios Ambientales. (2009). Agenda Ambiental Localidad 4 San Cristóbal, Alcaldía Mayor De Bogotá D.C, Bogotá.

[33] La Casa de la lluvia [de ideas] (San Cristóbal, Bogotá); Arquitectura www.arquitecturaexpandida.org.

[34] López Ortego, A., Lancheros F. (2015). Tácticas y estrategias de construcción territorial. III Foro de Urbanismo y Participación: el barrio como unidad politica emergente. Universidad La Salle, Bogotá.

[35] Fundación Bogotart: A territory conceived through the arts; Word Urban Campaign. http://www.worldurbancampaign.org/fundaci\%C3\%B3 n-bogotart-barrios-vivos-fucha-libre-vibrantneighborhoods-free-fucha-0.

[36] Fundación Bogotart: community integration and defense of the right to the city through art workshops; Word Urban Campaign. http://www.worldurbancampaign.org/fundaci\%C3\%B3 n-bogotart-community-integration-and-defense-rightcity-through-art-workshops.

[37] Respuesta Proposicion 258 de 2017; Secretaría Distrital De Habitat. https://www.habitatbogota.gov.co/sites/default/files/con trol/258-\%20Respuesta\%20SDHT.PDF.

[38] Arquitectura Expandida Segundo Lugar Premio Cívico Bogotá. 2013; Premio Cívico Por una Ciudad Mejor, https://www.porunaciudadmejor.com/videos accessed on Jan. 17, 2014. 